\title{
PERSIAPAN GURU SEKOLAH DASAR YANG PROFESIONAL DALAM MENGHADAPI GENERASI DIGITAL
}

\author{
Andri Anugrahana \\ Universitas Sanata Dharma \\ andrianugrahana@gmail.com \\ DOI: doi.org/10.24071/snfkip.2018.02 \\ diterima 12 Oktober 2018; diterbitkan 21 Desember 2018
}

\begin{abstract}
Abstrak
Makalah ini berisi tentang hasil analisa dan pembahasan mengenai tantangan yang akan dihadapi oleh calon guru Sekolah Dasar dalam menghadapi para peserta didik di era digital. Profesionalitas calon guru harus dihadapkan pada perubahan dalam kemajuan teknologi informasi dan perkembangan peserta didik di era digital. Perubahan itu dimulai dari tingkat sekolah dasar, maka penting untuk menyiapkan calon guru SD yang profesional. Persiapan yang dilakukan adalah mendidik calon guru yang melek teknologi dan selalu mengikuti perkembangan yang ada. Semua persiapan itu harus melibatkan seluruh kompetensinya sebagai guru yaitu kompetensi pedagogik, kepribadian, sosial dan profesional. Makalah ini bertujuan untuk memberi masukan bagi calon guru profesional dalam menyikapi dan menentukan strategi untuk menghadapai perkembangan di era digital. Makalah ini akan membahas hasil analisa diskriptif terhadap hasil questioner terhadap para calon guru professional PPG prajabatan tingkat SD di Universitas Sanata Dharma Jogjakarta. Analisa dan pembahasan dilakukan berdasarkan kompetensi dasar guru, yaitu kompetensi pedagogik, kepribadian, sosial dan professional. Hasil dari makalah ini adalah kesimpulan mengenai halhal yang harus ditekankan dalam mempersiapkan calon guru yang profesional di tingkat Sekolah Dasar dalam menghadapi segala aspek tuntutan dalam era digital.
\end{abstract}

Kata kunci: guru professional, kompetensi guru, era digital

\begin{abstract}
This paper contains the results of the analysis and discussion of the challenges that will be faced by prospective elementary school teachers in dealing with students in the digital era. Professionalism of teacher candidates must be faced with changes in the advancement of information technology and the development of students in the digital era. The change starts from the elementary school level, so it is important to prepare professional elementary teacher candidates. The preparation is to educate prospective teachers who are technologically savvy and always follow the developments. All preparations must involve all of his competencies as teachers, namely pedagogic, personality, social and professional competencies. This paper aims to provide input for prospective professional teachers in addressing and determining strategies to deal with developments in the digital era. This paper will discuss the results of the descriptive analysis of the results of the questionnaire on the prospective PPG professional teacher pre-
\end{abstract}


service at elementary level at Sanata Dharma University Jogjakarta. Analysis and discussion are carried out based on the teacher's basic competencies, namely pedagogic, personality, social and professional competencies. The results of this paper are conclusions about things that must be emphasized in preparing professional teacher candidates at the elementary school level in the face of all aspects of demands in the digital era.

Keywords: professional teachers, competencies as teachers, the digital era

\section{Pendahuluan}

Generasi muda yang akan datang adalah generasi yang mampu menghadapi persaingan yang semakin ketat dengan dunia lain. Maka dari itu penting menyiapkan generasi muda yang siap dalam menghadapi tatangan dunia yang semakin berkembang. Hal ini menjadi tanggung jawab besar bagi pendidik dalam menyiapkan generasi muda yang siap menghadapai tuntutan dunia yang terus berkembang. Peran guru tidak hanya mengajar saja tetapi guru harus mampu mengembangkan kemampuan dirinya dan perlu memiliki standar profesi dengan menguasi materi serta memiliki berbagai strategi pembelajaran yang dapat mendorong siswanya untuk siap menghadapi perkembangan dunia.

Undang - undang no 14 tahun 2005 pasal 1 menyebutkan bahwa guru adalah pendidik profesional dengan tugas utama mendidik, mengajar, membimbing, mengarahkan, melatih, menilai, dan mengevaluasi peserta didik pada pendidikan anak usia dini jalur pendidikan formal, pendidikan dasar, dan pendidikan menengah. Guru yang profesional juga dijelaskan dalam pasal 4 bahwa kedudukan guru sebagai tenaga profesional berfungsi untuk meningkatkan martabat dan peran guru sebagai agen pembelajaran berfungsi untuk meningkatkan mutu pendidikan nasional. Guru profesional memiliki tanggung jawab yang besar dalam meningkatkan mutu pendidikan. Kemajuan dan perkembangan anak-anak bangsa menjadi tanggung jawab pendidik. Keberhasilan dan kegagalan pendidikan menjadi ukuran dari keberhasilan guru. Guru menjadi salah satu faktor yang mempengaruhi tujuan pembelajaran dan pelaksanaan pembelajaran di sekolah.

Menurut Ismail (2010), guru yang profesional adalah guru yang berkompeten (berkemampuan). Kompetensi guru diatur dalam Undang undang Republik Indonesia No 14 tahun 2005 Pasal 10 ayat (1) menjelaskan bahwa kompetensi guru meliputi kompetensi pedagogik, kompetensi kepribadian, kompetensi sosial, dan kompetensi profesional yang diperoleh melalui pendidikan profesi. Keempat kompetensi yang dimiliki juga berdasar pada peraturan Menteri Pendidikan Nasional Indonesia Nomor 16 tahun 2007. Makalah ini bertujuan untuk untuk memberi masukan bagi calon guru profesional dalam menyikapi dan menentukan strategi untuk menghadapai perkembangan di era digital.

\section{Kajian Teori}

\section{Kompetensi Guru}

Nurtanto (2015) menjelaskan kompetensi guru merupakan kemampuan seorang guru dalam melaksanakan kewajiban-kewajiban serta tanggung jawab dan 
layak. Kompetensi pedagogik adalah kemampuan yang dimiliki guru dalam merancang pembelajaran, kemampuan melaksanakan proses pembelajaran, kemampuan menilai, proses dan hasil pembelajaran, kemampuan memanfaatkan hasil penelitian untuk meningkatkan kualitas pembelajaran. Kompetensi kepribadian meliputi, empati, berpandangan positif terhadap orang lain, berpandangan positif terhadap diri sendiri, Genuine (authenticity), berorientasi pada tujuan. Kompetensi sosial meliputi kemampuan menghargai keragaman sosial dan konservasi lingkungan, menyampaikan pendapat dengan runtut, efisien dan jelas, kemampuan membina suasana kelas, kemmpuan membina suasana kerja, dan kemampuan mendorong peran serta masyarakat. Kompetensi profesional meliputi pengguasaan materi kuliah secara luas dan mendalam, kemampuan meracang, melaksanakan dan menyusun laporan penelitian, kemampuan mengembangkan dan menyebarluaskan inovasi. Selanjutnya kemampuan merancang, melaksanakan dan menilai pengabdian kepadaasyarakat. Hal ini menunjukkan bahwa menjadi seorang guru merupakan tanggung jawab yang besar. Guru harus memiliki wawasan dan pengetahuan yang luas. Untuk itu guru harus memiliki kompetensi yang luas tentang pendidikan.

Guru dalam zaman digital adalah guru yang tidak hanya profesional dalam mengajar tetapi guru yang juga melek teknologi. Makna dari melek teknologi adalah guru yang tidak hanya berhenti dengan mengajar saja, tetapi guru yang selalu mengikuti perkembangan zaman. Perkembangan teknologi yang semakin pesat menuntut calon-calon guru ke depan untuk maju dan berkembang. Guru yang tidak mengikuti perkembangan akan tertinggal. Perkembangan teknologi berkembang sangat cepat dan akan menghasilkan generasi yang serba digital.

\section{Profesionalisme Guru}

Perkembangan teknologi yang semakin pesat dapat menimbulkan dampak negatif bagi generasi muda. Dampak tersebut dapay dilihat pada media masa, adanya kasus narkoba, tawuran antar sekolah, seks bebas, seks usia dini, dan lainlain. Perkembangan teknologi ini juga diharapkan menjadi motivasi bagi pendidik untuk mendampingi para generasi muda dalam menyikapi perkambangan teknologi yang semakin pesat. Mulcahi (2003) menguraikan di sejumlah negara sudah mengawali sebuah standard profesional terus berkembang. Hal ini didorong oleh tuntutan untuk akuntabilitas yang besar, pengajaran dan pembelajaran yang berkualitas, adanya reformasi pendidikam, kebutuhan untuk memperkuat profesi guru dan penilaian kinerja guru.

Indonesia sudah mulai mengembangkan standar profesional khususnya guru dalam meningkatkan kualitas pendidikan di Indonesia. Hal ini tertuang dalam Undang Undang RI No. 14 tahun 2005 pasal 2 ditegaskan bahwa: Guru mempunyai kedudukan sebagai tenaga profesional pada jenjang pendidikan dasar, pendidikan menengah, dan pendidikan anak usia dini pada jalur pendidikan formal yang diangkat sesuai dengan peraturan perundang-undangan. Hal ini memberikan kejelasan bagi calon guru dan guru terkait dengan profesionalisme yang harus dimiliki oleh guru. Dampak dari profesionalisme guru dapat mempengaruhi kualitas pendidikan. Pemerintah Indonesia memberikan perhatian yang cukup dalam rangka meningkatkan kualitas pendidikan yang dimulai dari pendidikan 
dasar. Salah satu perhatian itu adalah program profesi guru atau disebut juga PPG. PPG meliputi PPG dalam jabatan dan pra jabatan.

\section{Generasi Digital}

Generasi digital adalah generasi yang hidup di zaman yang memiliki kemudahan dalam mengakses informasi digital dan teknologi informasi. Generasi digital sering juga disebut digital native. Menurut Muzaki (2017) generasi yang terlahir dalam kubangan digital memiliki tantangan belajar dan peluang yang berbeda dibanding dengan generasi sebelumnya. Kemampuan dan ketersediaan teknologi bisa difasilitasi oleh guru untuk mengembangkan keterampilan mereka dalam menemukan infomasi. Hal ini juga didukung oleh pendapat dari Prensky (2001) yang juga berpendapat bahwa generasi digital merupakan generasi yang memiliki kesempatan belajar dengan mandiri.

Calon pendidik sudah selayaknya menyiapkan diri menghadapi tantangan generasi yang serba digital. Calon guru Sekolah dasar perlu menyiapkan diri memahami perangkat pembelajaran dengn mengganti perangkat yang konvensional dengan perangkat pembelajaran yang berbasis digital. Prensky (2001) menyebutkan tantangan pendidik adalah mendampingi generasi digital dan hal yang perlu dipertimbangkan adalah metodologi dan konten pedidik. Pertama, metodologi dimana guru zaman digital harus mampu belajar berkomunikasi dalam bahsa dan gaya siswa. Kedua, konten guru yang meliputi dua jenis konten yaitu: Legacy content dan Future content. Legency content meliputi membaca, menulis, berhitung, berpikir logis, memahami tulisan dan gagasan masa lalu, dll. Sedangkan future content yang berkaitan dengan digital dan teknologi seperti perangkat lunak, perangkat keras, robotika, nanoteknologi, genomik, dll.

\section{Metodologi}

Analisis data yang digunakan dalam penelitian ini adalah deskriptif naratif. Dengan melakukan tahapan yaitu mereduksi data, menyajikan data dan menarik kesimpulan. Data yang diperoleh dari lapangan berupa kuesioner terhadap calon guru profesional di prodi pendidikan guru sekolah dasar. Subjek dalam penelitian ini adalah calon guru profesional PPG Prajabatan di prodi pendidikan guru sekolah dasar Universitas Santa Dharma. Permasalahan yang akan dibahas dalam makalah ini adalah persiapan yang dilakukan oleh penggelola PPG, persiapan calon guru profesional dalam menyikapi perkembangan zaman yang serba digital dan Strategi yang dibangun oleh calon guru profesional untuk menghadapai perkembangan zaman yang semakin serba digital.

Hasil pembahasan dalam penelitian ini adalah memberikan gambaran persiapan yang dilakukan oleh calon guru pofesioanal, sikap yang sudah disiapkan oleh calon guru profesional dalam menyikapi perkembangan zaman yang serba digital dan strategi yang dibangun oleh calon guru profesional untuk mengahadapi perkembangan zaman yang semakin serba digital.

\section{Hasil dan Pembahasan}

Sikap yang perlu disiapkan sebagai calon guru profesional dalam menghadapi tantangan ke depan berkaitan dengan kompetensi kepribadian yang juga harus dimiliki oleh guru. Berikut kompetensi kepribadian ataupun sikap yang harus 
dimiliki calon guru profesional. Guru mampu bersikap dalam menghadapai tantangan di era digital, dengan cara mengupdate informasi baru, dengan lebih selektif dalam menggunakan teknologi. Guru akan mengarahkan siswa pada penggunaan teknologi yang positif seperti penggunaan teknologi untuk mencari informasi baru untuk menambah pengetahuan dan mengembangkan diri, menggunakan teknologi untuk memahami Pancasila untuk mendasari dunia milenial siswa. Hasil yang diharapkan calon guru profesional siap dalam menghadapi tantangan ke depan, dalam hal ini adalah sikap dalam menghadapi murid di tahun melenial yang serba digital. Sikap mereka dalam mengimbangi itu adalah mengimbangi pemahaman dan pengetahuan siswa dalam penggunaan teknologi, bahkan lebih maju.

Strategi yang dibangun oleh calon guru profesional untuk menghadapai perkembangan zaman yang semakin serba digital adalah persiapan guru profesional dengan meninjau kompetensi pedagogik. Persiapan yang dilakukan oleh pihak pengelola PPG dengan workshop dikampus dengan mendapatkan bimbingan dari dosen dan guru sekolah. Para calon guru profesional mendapatkan bimbingan selama satu semester. Setelah melakukan workshop di setiap minggunya, para calon guru profesional melakukan peerteaching di kelas. Peerteaching dilakukan dengan teman sebaya dan selanjutnya kedua dosen pembimbing memberikan penilaian. Selain itu bekal lain yang diperoleh oleh calon guru Sekolah Dasar.

Kegiatan-kegiatan yang dilakukan pengelola PPG yang mendukung penggembangan sebagai calon guru adalah. Upaya - upaya yang dilakukan penggelola profesi guru untuk membantu calon guru profesional khususnya dalam mengembangkan kompetensi pedagogik. Adapun kegiatan yang mendukung pengembangan pedagogik adalah kemampuan dalam menggelola pembelajaran peserta didik. Permendiknas No. 16, 2007 menyebutkan Kompetensi pedagogik meliputi 10 sub kompetensi Penulis menambahkan beberaa point yang penulis temukan dalam penggelolaan PPG. Kesepuluh kompetensi tersebut dijabarkan sebagai berikut khususnya kompetensi pedagogik.

Bentuk persiapan yang dilakukan pengelola PPG dalam pengembangan kompetensi pedagogik adalah sebagai berikut.

1. Penguasaan karakteristik peserta didik

Penguasaan dapat dilihat dari aspek fisik, moral, sosial, kultural, emosional, dan intelektual. Penguasaaan karakteristik dimunculkan dalam bentuk pelatihan adalah pelatihan "bela negara" dengan tujuan memahami pertahanan-pertahanan yang akan guru hadapi di daerah-daerah pedalaman. Kursus Mahir Dasar adalah bentuk pelatihan pramuka supaya calon guru profesional mampu membimbing siswanya. Pelatihan pembuatan media Batik. Pelatihan pembuatan yogurt dan parfum. Selain itu juga workshop penggunaan media Montessori.

2. Penguasaan teori belajar dan prinsip-prinsip pembelajaran yang mendidik

Para calon guru profesional mengikuti pendalaman materi teori belajar dan perkembangan peserta didik. Dengan begitu para calon guru profesional memiliki bekal dalam mendidik peserta didik. 
3. Pengembangan kurikulum

Pengembangan kurikulum yang terkait dengan mata pelajaran/bidang pengembangan yang diampu. Bentuk kegiatan yang dilakukan adalah melakukan pendalaman materi kurikulum. Selain itu juga pendalaman materi lima bidang keSDan yaitu bahasa, matematika, IPA, IPS dan PKN. Tujuan adanya pendalaman materi untuk menyiapkan ujian.

4. Penyelengaraan pembelajaran yang mendidik

Penyelengaraan pembelajaran dilakukan dengan mandiri dan dilakukan depan teman sejawat, selanjutnya teman sejawat bersama pembimbing memberikan penilaian.

5. Pemanfaatkan teknologi informasi dan komunikasi untuk kepentingan pembelajaran

Calon pendidik mendapat bekal merancang RPP (Rencana Pelaksanaan Pembelajaran) dengan berbasis pada pembelajaran berbasis teknologi informasi. Tidak hanya itu saja dalam rancangan tersebut para calon guru profesional juga sudah menerapkan pembelajaran berbasis IT.

6. Memfasilitasi pengembangan peserta didik untuk mengaktualisasikan berbagai potensi yang dimiliki

Potensi yang dimiliki sperti melakukan studi budaya yaitu kunjungan ke kraton, Sonobudaya, Taman Pintar, Taman sari. Pengrajin kulit di manding, gerabah dan pantai gua cemara.

7. Berkomunikasi secara efektif, empatik dan santun dengan peserta didik

Mendampingi siswa dengan tidak melarang tetapi menunjukkan akibat dari perilaku buruk dalam menggunakan teknologi. Menerima dan harus menyesuaikan diri untuk menghadapi perkembangan zaman yang serba digital. Guru melakukan pembimbingan pada siswa menemukan situs website yang kredibel.

8. Penyelengarakan penilaian dan evaluasi proses pembelajaran

Penilaian dilakukan saat calon guru dalam bentuk evaluasi dengan membuat dan merancang pembelajaran berbasis tindakan kelas. Tindakan kelas dilakukan untuk mengukur kualitas dari pembelajaran yang sudah dilakukan.

9. Pemanfaatkan hasil penilaian dan evaluasuntuk kepentingan pembelajaran.

Calon guru profesional meracang pembelajaran dan melakukan penilaian di kelas.

10. Melakukan tindakan reflektif untuk peningkatan kualitas pembelajaran.

Bentuk kegiatan yang menunjukkan tindakan reflektif adalah melakukan refleksi aecara individu dan juga berkelompok. Kegiatan refleksi kelompok dilakukan di asrama Shantikara.

Kompetensi kepribadian dalam PPG perlu dimiliki oleh calon guru yang profesional dan dapat menjadi teladan bagi siswa. Kepribadian guru mencerminkan karakter dari pribadinya dan menjadi contoh bagi anak didiknya.

1. Mampu bertindak sesuai dengan norma agama, hukum, sosial, dan kebudayaan nasional Indonesia. Seorang peserta didik yang memiliki kompetensi kepribadian akan mampu bertindak sesuai dengan norma.

2. Menampilkan diri sebagai pribadi yang jujur, berakhlak mulia, dan teladan bagi peserta didik dan masyarakat. Dengan mampu bersikap dalam menghadapai 
tantangan di era digital, artinya tidak terbawa arus tetapi menyikapi dengan menerima perkembangan yang ada dan tidak terbawa arus.

3. Mampu menampilkan diri sebagai pribadi yang mantap, stabil, dewasa, arif, dan berwibawa. Pribadi yang mantap, stabil, deawasa dan arif maupun berwibawa dapat mengimbangi pemahaman dan pengetahuan siswa dalam penggunaan teknologi, bahkan lebih maju.

4. Menunjukkan etos kerja, tanggung jawab yang tinggi, rasa bangga menjadi guru, dan rasa percaya diri. Pada era digital ini, bentuk rasa percaya diri dan tanggung jawab adalah dengan cara mengupdate informasi baru, dengan lebih selektif dalam menggunakan teknologi. Guru akan mengarahkan siswa pada penggunaan teknologi yang positif seperti penggunaan teknologi untuk mencari informasi baru untuk menambah pengetahuan dan mengembangkan diri, menggunakan teknologi untuk memahami Pancasila untuk mendasari dunia milenial siswa. Dan hasilnya mahasiswa siap dalam menghadapi tantangan ke depan, dalam hal ini adalah sikap dalam menghadapi murid di tahun melenial yang serba digital. Sikap mereka dalam mengimbangi itu adalah mengimbangi pemahaman dan pengetahuan siswa dalam penggunaan teknologi, bahkan lebih maju.

5. Menjunjung tinggi kode etik profesi guru. Bentuk menjunjung tinggi Dengan cara mengupdate informasi baru, dengan lebih selektif dalam menggunakan teknologi. Guru mengarahkan siswa pada penggunaan teknologi yang positif seperti penggunaan teknologi untuk mencari informasi baru untuk menambah pengetahuan dan mengembangkan diri, menggunakan teknologi untuk memahami Pancasila untuk mendasari dunia milenial siswa.

6. Memiliki sikap terbuka. Sikap terbuka adalah sikap yang selalu terbuka dengan mengikuti perkembangan yang ada. Keterbukaan dalam menerima masukan dengan menerima kritik dan saran, dengan begitu dapat menciptakan pembelajaran yang kreatif dengan memanfaatkan teknologi yang yang ada. Selalu terbuka dengan berinovatif menggunakan model-model pembelajaran yang ada.

Kompetensi sosial yang dimiliki guru adalah bentuk komunikasi yang dibangun dengan siswa, komunikasi dengan orang tua, komunikasi dengan pihak luar. Pengembangan kompetensi sosial bagi calon guru profesional adalah.

1. Bentuk komunikasi yang dapat dilakukan dengan siswa seperti mengikuti perkembangan bahasa yang sering digunakan anak, sehingga diharapkan dapat mencegah perilaku negatif dari anak. Selain itu juga guru berusaha memiliki akun media sosial ketika siswa memilikinya dan menyarankan mereka untuk berteman dengan guru di jejaring sosial sebagai wadah untuk belajar, media komunikasi dan melakukan pengawas aktivitas siswa di dunia maya. Selain itu penting sebagai pendidik mengenali berusaha mengenali potensi masing-masing siswa agar lebih efektif dalam mendidik.

2. Membangun komunikasi dengan orang tua. Pendidikan tidak hanya menjadi tanggung jawab guru di sekolah tetapi juga menjadi tanggung jawab orang tua. Dengan melakukan kerjasama antara guru dan orang tua. Bentuk komunikasi dengan orang tua adalah dengan mengajak wali murid untuk mengawasi dan membimbing putra-putri mereka. Selain itu pendampingan dari orang tua selama belajar dan akses di dunia maya atau internet. Guru dan orang tua meningkatkan 
pengawasan terhadap siswa di sekolah dan bekerja sama dengan orangtua untuk mengawasi siswa di rumah. Karena pendidikan itu tidak hanya dilakukan siswa di sekolah tetapi juga di rumah. Maka penting dukungan dan menjadi perhatian orang tua.

3. Berkomunikasi pihak luar. Pihak luar dalam hal ini adalah selain orang tua atau wali tetapi juga artinya bahwa menjadi seorang guru juga harus mengikuti perkembangan sosial yang ada di media sosial. Cotohnya mengikuti forum-forum guru sehingga membantu guru mengetahui perkembangan yang ada. Selain itu mengikuti perkembangan yang ada di Media sosoial, seperti mengikuti jaringan sosial yang sering dikunjungi oleh siswa. Hal ini menjadi salah satu bentuk monitoring guru di sekolah. Dengan begitu guru akan mengetahui apa saja yang dilakukan siswa di media sosial. Berkomunikasi dengan komunitas profesi sendiri dan profesi lain secara lisan dan tulisan atau bentuk lain. Beradaptasi di tempat bertugas di seluruh wilayah Republik Indonesia yang memiliki keragaman sosial budaya. Berkomunikasi secara efektif, empatik, dan santun dengan sesama pendidik, tenaga kependidikan, orang tua, dan masyarakat. Guru harus memiliki kepribadian yang selalu berusaha mejadi teladan pada anak didik. Keteladanan itu dalam bentuk sikap sebagai seorang guru. Peduli, berempati dan berusaha mengajarkan kebaikan kepada para siswa.

Standar Nasional Pendidikan, Pasal 28 ayat (3) butir d, dikemukakan bahwa kompetensi yang dimiliki oleh guru adalah kompetensi sosial yang berkaitan dengan komunikasi secara efektif dan empatik dengan peserta didik, orang tua peserta didik, sesama pendidik, tenaga kependidikan dan masyarakat (Sukanti, 2008). Berikut adalah kompetensi profesional meliputi.

1. Menguasai materi, struktur, konsep, dan pola pikir keilmuan yang mendukung mata pelajaran yang diampu.

Calon guru profesional mendapatkan pembekalan oleh pengelola PPG yaitu pendalaman materi lima bidang keSDan yaitu bahasa Indonesia, PKN, IPS, IPA dan matematika. Tidak hanya itu saja tetapi juga mendapatkan pendalaman materi pedagogik.

2. Menguasai standar kompetensi dan kompetensi dasar mata pelajaran/bidang pengembangan yang diampu.

Pendalaman materi tentang kurikulum yang sedang berlaku, untuk saat ini pendalaman terkait kurikulum 2013. Calon guru profesional mengkaji dan menganalisis kompetensi-kompetensi yang termuat dalam kurikulum. Selanjutnya calon guru profesionl akan merancang dan menyusun rancangan pembelajaran mulai dari silabus, rrp dan juga media dan bahan ajar yang digunakan.

3. Mengembangkan materi pembelajaran yang diampu secara kreatif

Perlu disadari untuk menjadi guru yang kreatif

4. Mengembangkan keprofesionalan secara berkelanjutan dengan melakukan tindakan reflektif.

Hal ini sudah dilakukan oleh calon guru dengan membuat refleksi dan melakukan refleksi secara bersama-sama.

5. Memanfaatkan teknologi informasi dan komunikasi untuk berkomunikasi dan mengembangkan diri. 
Guru yang tidak hanya mengajar saja tetapi guru yang juga melek informasi dengan selalu mengupdate informasi baru dan selalu mengikuti perkembangan yang ada.

Strategi yang dibangun sebagai calon guru professional untuk menghadapai perkembangan zaman yang semakin serba digital. Hasil kuesioner calon guru profesional dibaggi atas dua strategi yaitu strategi dari dalam diri dan strategi dari luar diri.

1. Strategi dari dalam diri

a. Bersiap diri dengan melakukan pengembangan kompetensi teknologi informatika terhadap diri sendiri baik secara mandiri ataupun dengan mengikuti pelatihan. Selanjutnya mengajarkan materi berdasarkan perkembangan zaman, selama sekolah memiliki fasilitas yang memadai. Guru dapat merancang dan mengembangkan pengalaman belajar era digital dengan mengembangkan lingkungan belajar yang kaya akan teknologi yang memungkinkan siswa merasa ingin tahu dan aktif.

b. Memperkaya pengetahuan dengan selalu belajar tentang banyak hal yaitu seperti pemanfaatan teknologi (software) khususnya yang mendukung pembelajaran, contohnya dengan membuat video. Memanfaatkan teknologi itu sendiri dalam pembelajaran sehingga pembelajaran akan menjadi lebih kreatif dan inovatif dengan bernovasi dalam merancang kegiatan pembelajaran. Terbuka terhadap masukan-masukan dari orang lain terkait penggunaan TIK. Guru yang selalu berinovatif adalah guru yang selalu meng-upgrade diri sendiri dan berusaha agar tidak ketinggalan zaman, selalu belajar dan mencari tahu terkait dengan trend-trend di masa itu sehingga bisa paham keadaan dan kondisi di masa itu. Guru belajar mengikuti perkembangan zaman dengan meningkatkan skill teknologi dan memperdalam digital learning. Merancang dan mengembangkan pengalaman belajar era digital dengan mengembangkan lingkungan belajar yang kayak akan teknologi yang memungkinkan siswa merasa ingin tahu dan aktif.

c. Memiliki pengetahuan tentang psikologi anak agar memahami kepribadian, keunikan dan karakter siswa yang berbeda-beda. Guru memiliki pengetahuan yang cukup tentang karakteria anak didik sehingga guru dapat mengambil sikap dalam mendampingi pertumbuhan dan perkembanan anak didik.

d. Menjadi role model untuk peserta didik yang kritis dan kreatif. Guru mendidik anak menjadi pencetus digital bukan hanya peminat digital dengan cara meminta anak untuk berkreatif dengan membuat blog atau video edukatif, dll.

2. Strategi dari luar

a. Pendampingan dari orang tua.

Menerapkan parenting control system. Tujuannya adalah orang tua juga dilibatkan dalam perkembangan anak didik. Bekerjasama dan memberikan arahan kepada orangtua untuk mengontrol penggunaan gadget.

b. Pengenalkan pendidikan agama yang kuat pada anak.

Mengenalkan pada anak dampak positif dan negatif dari setiap tindakan dengan memaksimalkan dampak positif untuk mendukung proses kegiatan belajar. c. Komunikasi dengan siswa dalam Peningkatkan keterampilan komunikasi dengan pihak yang berhubungan dengan siswa. 
Guru dapat menjadi teman bagi siswa misalnya bersikap selayaknya teman ketika mengingatkan siswa untuk bijak dalam memanfaatkan teknologi bukan bersikap sok menggurui. Guru juga dapat memfasilitasi dan menginspirasi belajar dan kreativias siswa. Memberikan sosialisasi teknologi untuk memaksimalkan adanya perkembangan digital.

d. Menjadi model cara belajar dan bekerja yang di era digital dengan berkolaborasi dengan pihak-pihak terkait menggunakan cara dan sumber digital untuk mendorong keberhasilan dan inovasi siswa.

e. Komunikasi antar guru

Berkonstribusi terhadap efektifitas, vitalitas, dan pembaharuan diri terkait dengan profesi guru. Seperti saat ini sudah ada media sosial yang memfasilitasi guru-guru seluruh Indonesaia. Sehingga semua guru dapat saling berkomunikasi satu dengan yang lain. Bahkan dapat saling bertukar pengetahuan dan ilmu.

\section{Kesimpulan}

Berdasarkan hasil penelitian ini, persiapan yang dilakukan pengelola dalam menyiapkan calon guru yang profesional dapat dilihat dari kompetensi yang harus dimiliki oleh guru. Kompetensi tersebut adalah kompetensi pedagogik, kompetensi kepribadian, kompetensi sosial dan kompetensi profesional. Kompetensi pedagogik meliputi : 1) Penguasaan karakteristik peserta didik, 2) penguasaan teori belajar dan prinsip-prinsip pembelajaran yang mendidik, 3) pengembangan kurikulum, 4) penyelengaraan pembelajaran mendidik, 5) Pemanfaatan teknologi informasi dan komunikasi, 6) memfasilitasi pengembangan peserta didik, 7) berkomunikasi secara efektif, 8) Penyelengaraan penilaian dan evaluasi, 9) pemanfaatan hasil penilaian dan evaluasi, dan 10) melakukan tindakan refleksi. Kompetensi kepribadian meliputi : 1) mampu bertindak sesuai norma, 2) mampu menampilkan diri sebagai pribadi yang jujur, berakhlak mulia, dan menjadi teladan dalam masyarakat, 3) menampilkan diri sebagai pribadi yang mantap, 4) menunjukkan etos kerja, 5) menjunjung tinggi kode etik profesi guru, 6) memiliki sikap terbuka. Kompetensi sosial meliputi: 1) komunikasi dengan siswa, 2) orang tua dan 3) pihak luar. Kompetensi profesional meliputi : 1) menguasai materi, struktur, konsep dan pola pikir keilmuan, 2) Menguasai stadar kompetensi dan kompetensi dasar mata pelajaran yang diampu, 3) mengembangkan materi pembelajaran secara kreatif, dan 4) mengembangkan profesionalan secara bekelanjutan dengan melakukan tindakan reflektif, 5) memanfaatkan teknologi informasi da komunikasi.

Berdasarkan hasil yang telah didapat, terdapat beberapa saran yang dapat dijadikan pertimbangan dan referensi selanjutnya. Saran-saran tersebut adalah: 1) Hasil kuesioner dapat dikaji lebih dalam lagi dengan melakukan wawancara secara medalam sehingga dapat memperoleh data yang lebih lengkap, 2) melakukan penelitian pada aspek yang lain yaitu pengelolaan profesi guru, pelaksanaan profesi guru dan lain-lain. 


\section{Daftar Pustaka}

Ismail, I. (2010). Kinerja dan kompetensi guru dalam pembelajaran. Jurnal Lentera Pendidikan, 13(1), 44-63.

Mulcahi. (2003). Teaching standards and professionalism in TAFE: Prospects, possibilities and pitfalls.

http://citeseerx.ist.psu.edu/viewdoc/download?doi=10.1.1.567.5834\&rep=rep $1 \&$ type $=$ pdf

Muzaki, I. F. (2017). Membelajarkan generasi digital di SD. http://lib.um.ac.id/wp-content/uploads/2017/07/Guru-SD-untuk-DigitalNative.pdf, diakses tanggal 1 Oktober 2018.

Nurtanto. (2015). Mengembangkan kompetensi profesionalisme guru dalam menyiapkan pembelajaran yang bermutu.

http://www.jurnal.fkip.uns.ac.id/index.php/snip/article/viewFile/8975/6535

Peraturan Mentri Nomor 16 tahun 2007. http://vervalsp.data.kemdikbud.go.id/prosespembelajaran/file/Permendiknas $\% 20$ No\%2016\%20Tahun\%202007.pdf

Prensky, M. (2001). Digital natives, digital immigrants. The Horizon, 9, 2-4. Retrieved from http://www.marcprensky.com/digital-native/, diakses tanggal 1 Oktober 2018.

Sukanti. (2008). Meningkatkan kompetensi guru melalui pelaksanaan tindakan kelas. Jurnal Pendidikan Akutansi Indonesia, 6(1). Dikutip dari https://journal.uny.ac.id/index.php/jpakun/article/view/1786/1480

Sutarmanto. Kompetensi dan profesionalisme guru pendidikan anak usia dini. Jurnal Ilmu Pendidikan FKIP-UNTAN Pontianak. http://download.portalgaruda.org/article.php?article=33621\&val=2347

Undang-undang Republik Indonesia No 14 tahun 2005 (http://luk.staff.ugm.ac.id/atur/UU14-2005GuruDosen.pdf) didownload tanggal 27 September 2018.

Undang-undang No. 14 tahun 2005 tentang guru dan dosen https://ainamulyana.blogspot.com/2018/06/undang-undang-uu-nomor-14tahun-2005.html 